\title{
Intrahypothalamically Transected Neurosecretory Axons do not Regenerate in the Absence of Glial Cells
}

\author{
H. -Dieter Dellmann and Jeanine Carithers \\ Department of Veterinary Anatomy and Neurosciences Program \\ Iowa State University, Ames, IA 50011, USA
}

\section{SUMMARY}

Fifteen days after transection of the hypothalamo-neurohypophysial tract at the lateral retrochiasmatic hypothalamic area, neurosecretory axons had vigorously regenerated into transplants of explanted hypophysial neural lobe, to a lesser extent into sciatic nerve transplants, and least into of tic nerve transplants. Regenerating axons were always closely associated with the specific glial cells of these grafts. When these glial cells were killed by cryotreatment prior to transplantation, neurosecretory axons did not regenerate into the abundant extracellular matrix of the transplants, including persisting basal lamina tubes in neural lobe and sciatic nerve grafts. The presence of viable glial cells is a prerequisite for neurosecretory axon regeneration.

\section{KEY WORDS}

neurosecretory neurons, transection, neurophysin immunohistochemistry, electron microscopy, glial cells, regeneration

\section{INTRODUCTION}

Contrasting with the robust regeneration of neurosecretory axons that occurs following transection of the hypothalamo-neurohypophysial tract at the median eminence $/ 7,19,31,32,37 /$ is the viridal lack of a regenerative response when the same tract is transected intrahypothalamically $16,27,34 /$; the latter neurosecretory axons do, however, regenerate to a limited degree into perivascular connective tissue spaces in the vicinity of the transection site, or into suitable microenvironments provided by tissues transplanted into contact with the proximal stumps of the severed axons. Syngeneic grafts of hypophysial neural lobe $/ 12 /$, sciatic nerve $/ 10 /$, optic nerve $/ 14 /$, and hypophysial neural lobe explants $/ 4 /$ are invaded to varying degrees by regenerating neurosecretory axons, which form perivascular plexuses around the microvessels of the grafts. When the ventral hypothalamic surface is damaged during the transection procedure, vigorous regeneration occurs into the leptomeninges $/ 13 /$.

Neurosecretory axon regeneration always occurs in close association with glial cells, i.e., pituicytes in neural lobe grafts, neurolemmocytes in sciatic nerve grafts, astrocytes in optic nerve grafts, and neurolemmocyte-like cells in the meninges. Glial cells thus seem to play an essential role in the regeneration process. In order to verify that role, we have killed glial cells by cryotreatment of the above tissue types prior to transplantation, to determine whether their absence from the grafts precludes neurosecretory axon regeneration.

Reprint address:

H. -Dieter Dellman

Department of Veterinary Anatomy

Iowa State University

Ames, IA 50011, USA 


\section{MATERIAL AND METHODS}

Adult male Holtzman rats (250-275 g) were anesthetized with ketamine-pentobarbital $(60 \mathrm{mg}$ ketamine $/ \mathrm{kg} / \mathrm{i} . \mathrm{m}$.; $20 \mathrm{mg}$ pentabarbital $/ \mathrm{kg} / \mathrm{i} . \mathrm{p}$.). The hypothalamo-neurohypophysial tract was transected bilaterally with a $1.5 \mathrm{~mm}$ wide wire loop knife at the lateral retrochiasmatic area $/ 30 /$, using stereotactic procedures (in relation to bregma: $\mathrm{AP}=$ $1.2 \mathrm{~mm} ; \mathrm{LM}=0.8-1.0 \mathrm{~mm} ; \mathrm{DV}=8.5 \mathrm{~mm}$ ). Lesions were then assigned to a control group in which no transplant was placed, or to one of six groups based on the source and treatment of transplanted tissue. The six types of transplants placed with a 19-gauge spinal needle into the transected hypothalamo-neurohypophysial tract in the lateral retrochiasmatic area were: (1) hypophysial neural lobe explants (after 30 days in vitro) $/ 9 /(\mathrm{n}=5)$; (2) cryotreated hypophysial neural lobe explants $(\mathrm{n}=9)$; small pieces $\left(0.25 \mathrm{~mm}^{3}\right)$ of (3) sciatic nerve $(n=3) ;(4)$ cryotreated sciatic nerve $(n=8) ;(5)$ optic nerve $(n=9) ;(6)$ cryotreated optic nerve $(n=6)$. The cryotreatment consisted of three freeze-thaw cycles prior to transplantation.

Fifteen or 20 days after transplantation, pentobarbital-anesthetized rats were fixed by aortic perfusion with a phosphate-buffered $(0.2 \mathrm{M}, \mathrm{pH}$ 7.2) $2 \%$ glutaraldehyde- $3 \%$ paraformaldehyde solution. Brains were removed and placed in the same fixative for an additional 6 to 12 hours. Alternate $50 \mu \mathrm{m}$ thick, vibratome-cut horizontal sections of the hypothalamus were then processed for immunohistochemistry and electron microscopy. The immunohistochemical procedure, which identifies both vasopressin-associated and oxytocin-associated neurophysin, was as previously published /13/. For electron microscopy, sections were postfixed in $2 \% \mathrm{OsO}_{4}$ and $0.75 \%$ potassium ferricyanide, stained for $3 \mathrm{~h}$ in $2 \%$ uranyl acetate and embedded in eponaraldaite. This sections were stained with lead citrate.

\section{RESULTS}

Detailed accounts of the immunohistochemical and fine structural characteristics of noncryotreated neural lobe explants, sciatic nerve and optic nerve have been published previously
$14,8,10,14 / ;$ therefore only a concise description of these tissues is included here to permit comparison with the cryotreated transplants.

\section{Transplants of neural lobe explants}

In non-cryotreated neural lobe explants, neurosecretory axons were frequently more concentrated peripherally, at the interface between graft and host, and were abundant throughout the grafted tissue (Fig. 1a). Usually a punctate immunostaining prevailed, indicative of neurovascular contact regions (Fig. 1b) and in some areas the reaction was weak (Fig. 1a). In cryotreated neural lobe explants no neurophysin immunoreactivity was detected (Fig. 2a).

The fine structural characteristics of noncryotreated neural lobe explants were similar to those of intact neural lobes $/ 12 /$, except for a greater abundance of connective tissue in some areas. Axons filled with densely packed neurosecretory granulated vesicles were fully or partially ensheathed by pituicyte processes, and they terminated at perivascular basal laminae or their evaginations into the surrounding neuropil (Figs. 1b, c). Both fenestrated and continuous capillaries were abundant.

Cryotreated transplants of explanted neural lobe lacked pituicytes, and neurosecretory axons were also absent, except peripherally (see below) (Fig. $2 b$ ). Scattered fibrocytes, many basal lamina remnants (Fig. 2c), macrophages alone or in groups, and scarce fenestrated and continuous capillaries lay among densely packed and abundant collagen fibrils with little amorphous ground substance (Fig. 2b).

\section{Transplants of sciatic nerve}

Non-cryotreated sciatic nerve transplants contained numerous neurosecretory axons (Fig. 3a), as evidenced by neurophysin immunoreactivity. Cryotreated transplants, in contrast, did not support neurosecretory axon regeneration (Fig. 4a).

At the fine structural level, non-cryotreated transplants were characterized by bundles of neurosecretory axons invested by basal laminaensheathed Schwann cells. Endoneurial collagen 


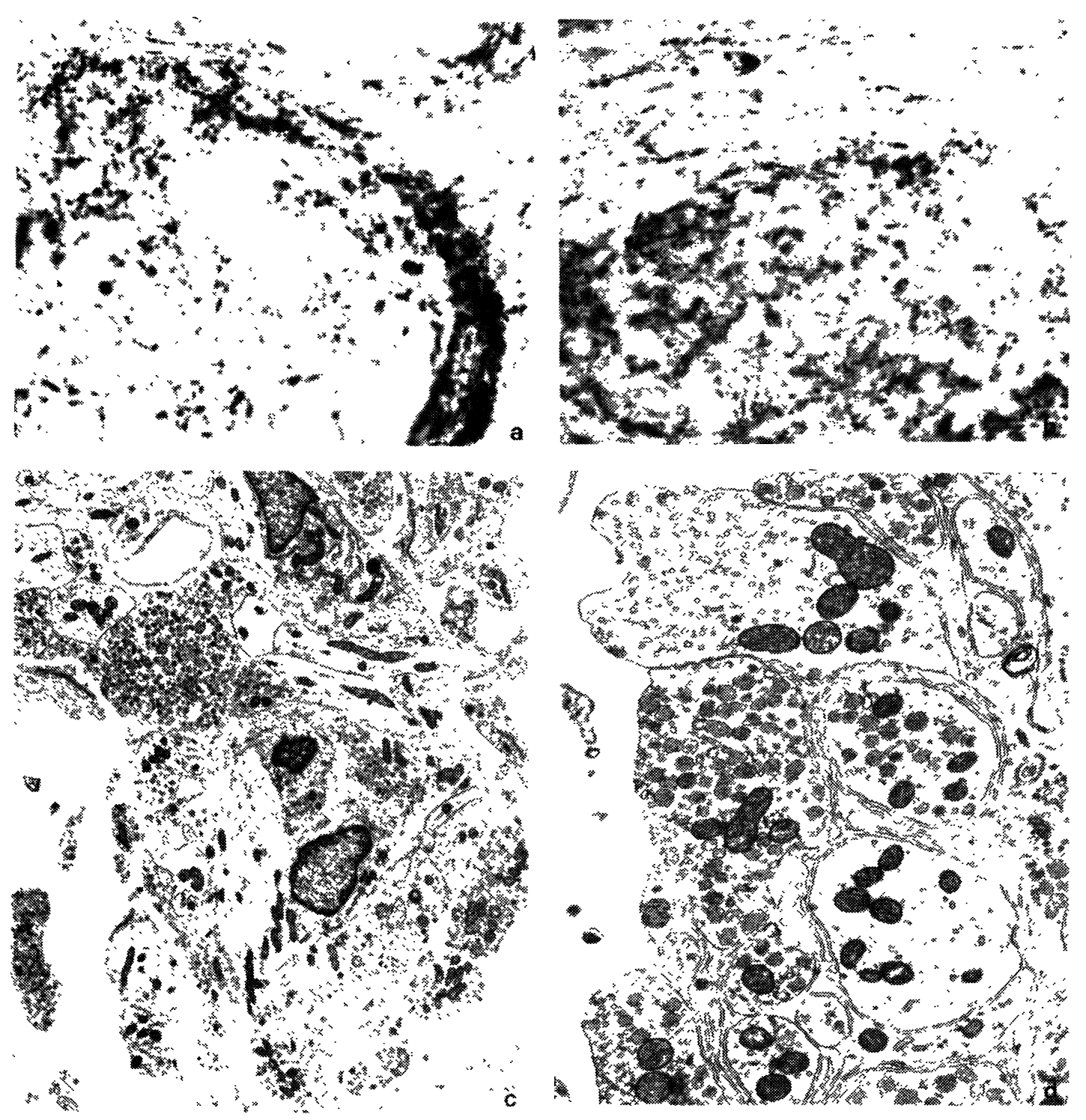

Fig. 1: Transplants of non-cryotreated neural lobe explants. a: A dense layer of neurosecretory axons surrounds this transplant and numerous axons are present in the transplant in which areas of more intense immunoreactivity indicate perivascular terminals. $x$ 460. b: This transplant lacks the surrounding layer of neurosecretory axons. Neurovascular contact regions are more extensive than in a. The punctate immunoreactive material represents axon terminals and groups of axon terminals, while the empty appearing regions are capillaries. $x$ 460. c: Profiles of neurosecretory axons and axon terminals have the same relationship with pituicytes as in the intact neural lobe. $x$ 7600. $d$ : Axons and axon terminals abutting the perivascular basal lamina are partially or entirely invested by pituicyte lamellopodia. $x 19200$. 

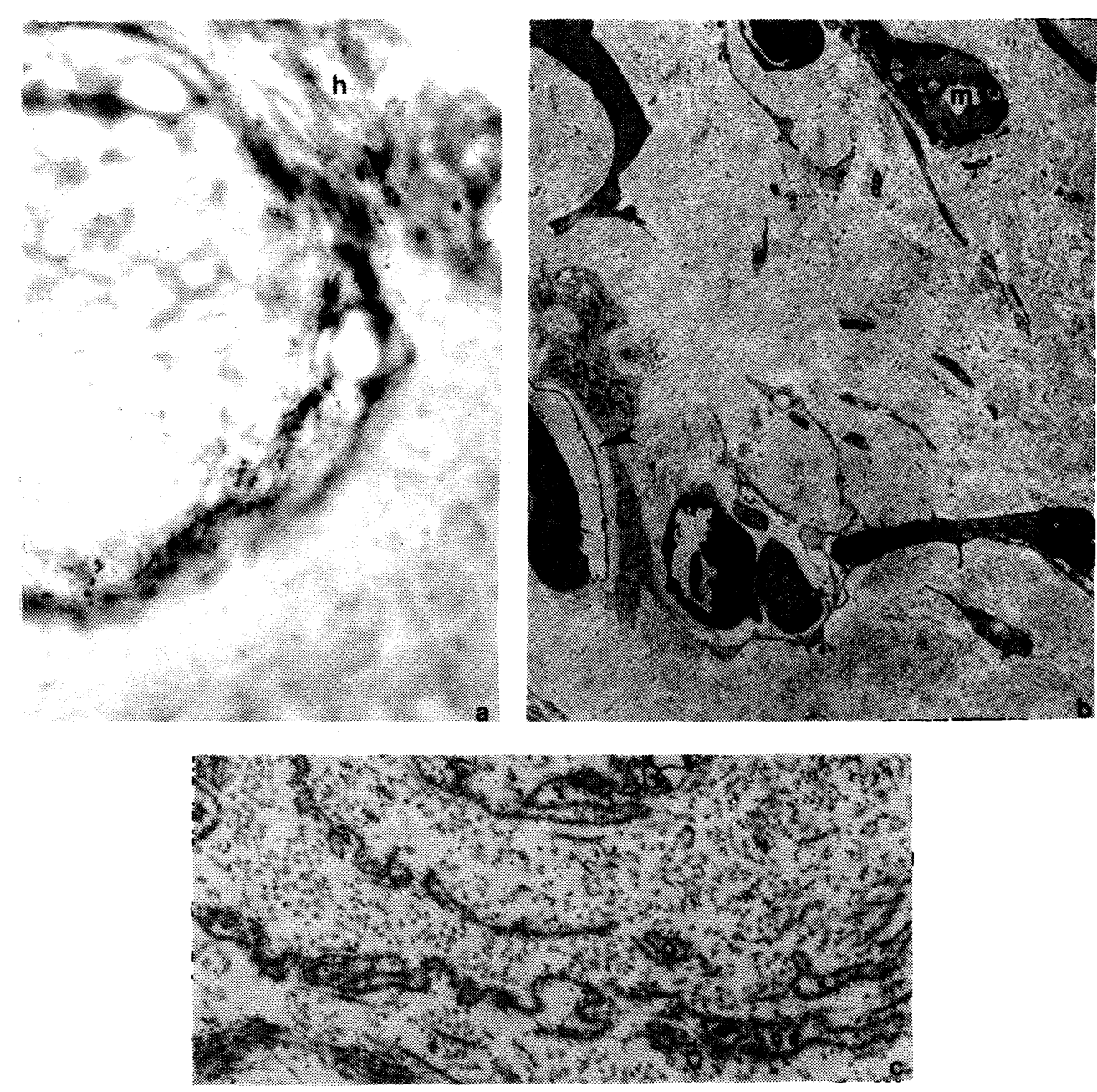

Fig. 2: Transplants of cryotreated neural lobe explants. a: Neurosecretory axons are present only in the host (h) and at the interface between host and graft. Axons seemingly penetrating the transplant belong to the interface layer. $x$ 460. b: Within the predominant extracellular matrix, notice continuous capillaries and a fenestrated capillary (arrowhead), fibrocytes and part of a macrophage $(\mathrm{m}) . \times 3500$. c: Basal lamina remnants in the extracellular matrix. x 21000.

fibrils and fibrocytes surrounded the bundles (Fig. $3 b)$.

In cryotreated transplants, Schwann cells were no longer present, but their collapsed empty basal lamina tubes remained, and were surrounded by abundant extracellular connective tissue matrix (Figs 3c, 4b). Most capillaries were continuous, but a few fenestrated capillaries were observed (Fig. $4 b)$. Fibrocytes and a few macrophages were scattered throughout the transplants (Fig. 4b). Neurosecretory axons were absent, except peripherally (see below).

\section{Transplants of optic nerve}

Non-cryotreated transplants contained regenerating immunoreactive neurosecretory axons that had a distinct affinity for the microvasculature, around which they formed plexuses of varying density (Fig. 5a). Cryotreated transplants failed to promote neurosecretory axon regeneration (Fig. 6a), except peripherally (Fig. 6b) (see below).

With the electron microscope, single neurosecretory axons were observed between densely packed astrocytes in non-cryotreated 

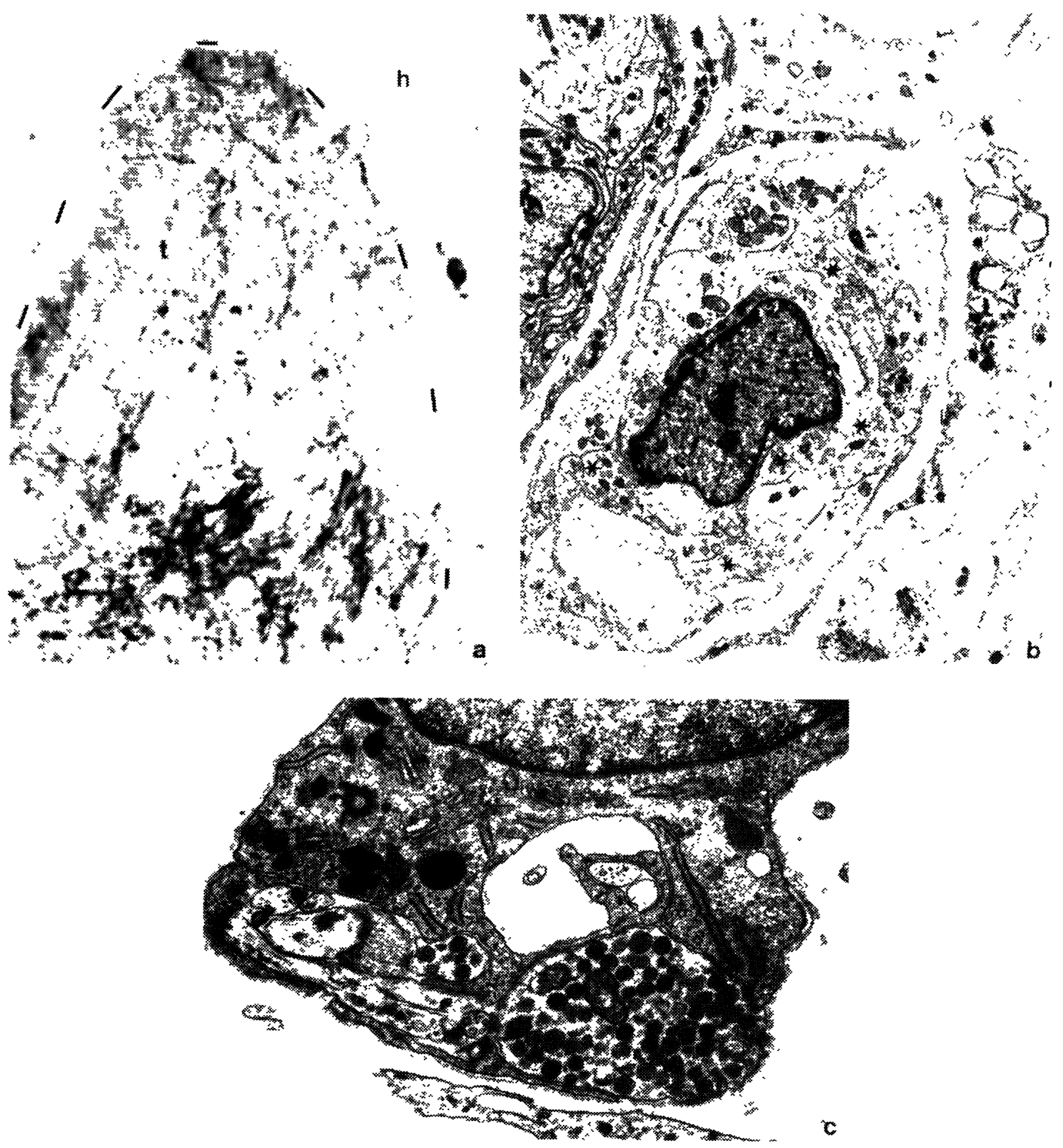

Fig. 3: Transplants of non-cryotreated sciatic nerve. a: Many neurosecretory axons have penetrated the transplant ( $t$ ) that is clearly delineated (interrupted line) from the host $(\mathrm{h})$. Neurosecretory axons are denser in a piece of transplant (bottom of picture) that is connected to the host at a different level. $x 460$. b: Bundles of neurosecretory axons containing neurosecretory granulated vesicles (asterisks) and/or microvesicles indicative of hormone release, are related to Schwann cells in a manner similar to that observed in intact peripheral nerves. $\mathrm{x} 7600$. c: The typical relationship between neurosecretory axons and a basal lamina-enclosed Schwann cell is shown in this micrograph. $\mathbf{x} 20000$.

transplants. Bundles of neurosecretory axons associated with basal lamina-enclosed astrocyte processes were especially numerous in perivascular connective tissue spaces (Fig. 5b).

In cryotreated transplanted, collagen fibrils were considerably less abundant than in the other graft types. Macrophages were the predominant cell type; astrocytes and oligodendrocytes were no longer identifiable (Fig. 6b). Grafts contained both continuous capillaries and a few fenestrated capillaries (Fig. 6b). Neurosecretory axons were only observed in the graft periphery (Figs. 6b, c). 


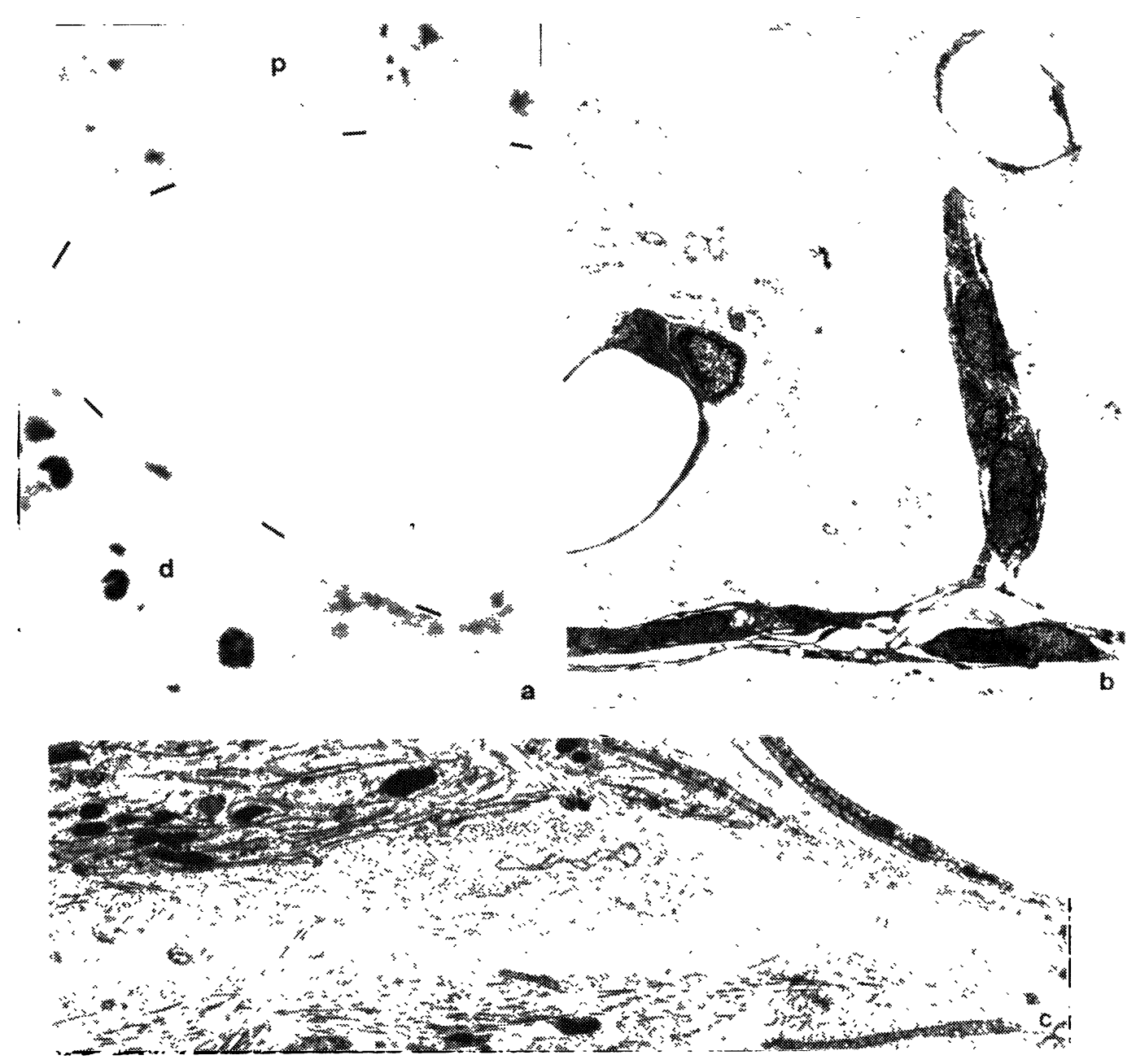

Fig. 4: Transplants of cryotreated sciatic nerve. a: Neurosecretory axons are absent from this transplant but present in the hypothalamus proximal to it (p). Distally (d) degenerating neurosecretory axons have formed immunoreactive "retraction balls". x 460. b: Fibrocytes and fenestrated capillaries are surrounded by copious extracellular matrix. x 4200. c: Collapsed basal lamina tubes remain after the disappearance of the Schwann cells. $x 8400$.

\section{All transplants}

Regenerating neurosecretory axons that did not form terminals occasionally penetrated the periphery of all types of transplants. Invariably, these axons were accompanied by basal laminasurrounded astrocytic processes from the host (Figs. 6c, 7a, b). Neurosecretory axons were never observed without investment of host glia.

\section{DISCUSSION}

In previous investigations we have shown that intrahypothalamically transected neurosecretory axons regenerate into transplants of intact neural lobe, neural lobe explants, sciatic nerve and optic nerve $/ 4,10,12,14 /$. Perivascular connective tissue spaces of hypothalamic blood vessels likewise provide a conducive microenvironment for regenerating neurosecretory axons $/ 1,11 /$, and the meninges support neurosecretory axon regeneration over long distances /13/. In all these diverse microenvironments, regenerating neurosecretory axons are almost always associated with glial cells; only exceptionally are naked neurosecretory axons observed. These observations suggest that a close 

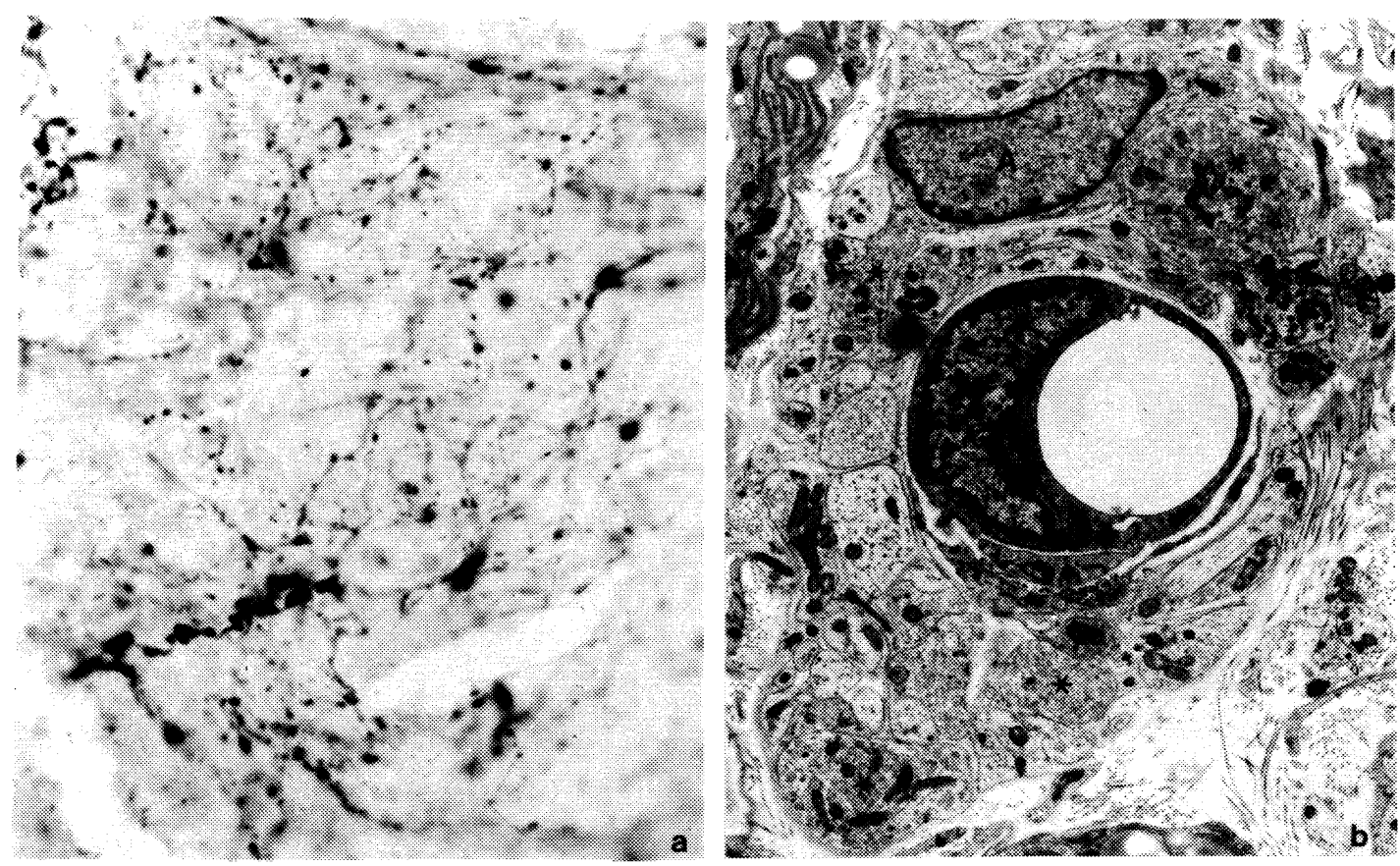

Fig. 5: Transplants of non-cryotreated optic nerve. a: Rather vigorous regeneration has taken place into this transplant. The more densely staining areas in the bottom half of the picture represent neurovascular contact regions. $x$ 460. b: Perivascular bundles of regenerated neurosecretory axons containing neurosecretory granulated vesicles (asterisks) and/or microvesicles are invested by an astrocyte (A) and astrocyte processes. $x 7600$.

association between glia and transected axons is a prerequisite for regeneration. The data reported here strongly support the notion that the presence of viable glial cells is indispensable for neurosecretory axon regeneration.

Cryotreatment effectively kills neurolemmocytes in peripheral nerves $/ 17,18,29,36 /$, pituicytes in neural lobe explants (4) and astrocytes and oligodendrocytes in optic nerves (present investigation). Fifteen days after transplantation, cryotreated neural lobe and sciatic nerve grafts are primarily composed of fibrocytes (whether indigenous to the graft or of host origin is unknown), abundant collagen and amorphous extracellular matrix, and some macrophages. These cells predominate in cryotreated optic nerve transplants, and connective tissue components are distinctly less abundant than in the other two types of transplants, which is likely due to the relative scarcity of these elements in the intact optic nerve, especially when the organ is divested of its meningeal covering, which was the case in our transplants. In neural lobe and sciatic nerve grafts fragments of basal lamina and collapsed basal lamina tubes are also present, but neither of these elements supports neurosecretory axon regeneration.

Basal lamina components have been suggested as substrates for axonal regeneration (for review see /17/), and basal lamina tubes have been shown to support regeneration in the peripheral nervous system $/ 15,17,18,20 /$. Empty basal lamina tubes are commonly found in both predegenerated sciatic nerve grafts and neural lobe grafts, but neurosecretory axons have not been observed to regenerate into these tubes without accompanying neurolemmocytes or pituicytes $/ 8,12 /$. Therefore, basal lamina alone does not support regeneration of neurosecretory axons, even in tissue that has not been cryotreated. The absence of glial cells in cryotreated grafts, therefore, is clearly the reason that regeneration does not occur. This conclusion also holds true for non-neurosecretory CNS axons $/ 18,36 /$. 


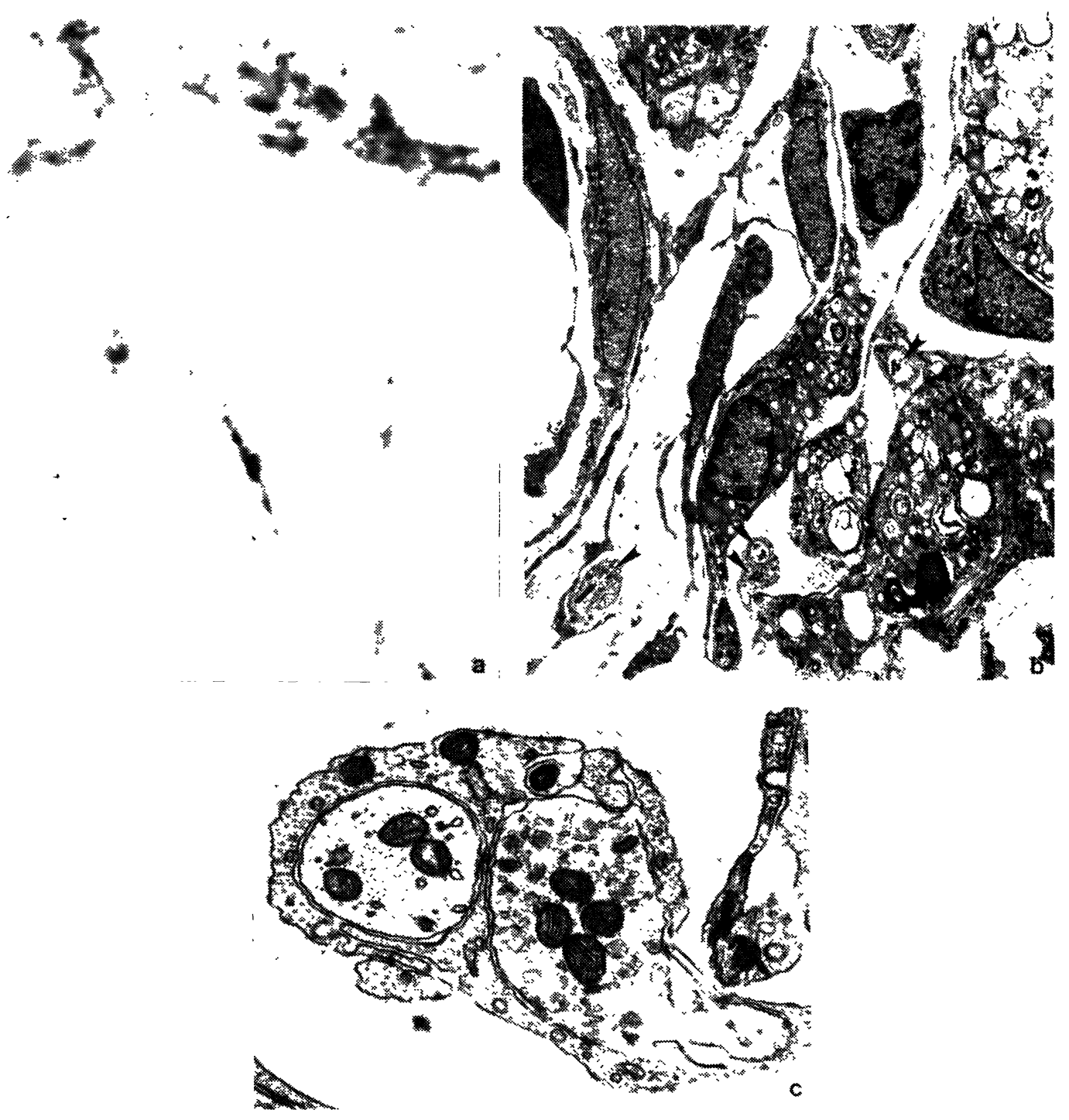

Fig. 6: Transplants of cryotreated optic nerve. a: A single neurosecretory axon has penetrated this transplant. $x$ 460. b: Fibrocytes and macrophages are surrounded by extracellular matrix in the vicinity of a fenestrated capillary. Four neurosecretory axons invested by astrocyte processes are present (arrowheads; micrograph taken in the graft periphery). $x$ 5250. c: Higher magnification of the double arrow-labeled bundle in Fig. $5 \mathrm{~b}$ to illustrate the relationship between astrocyte processes and neurosecretory axons. $\mathrm{x} 30000$.

Blood-borne factors have been implicated in the initiation of regenerative events $/ 21 /$, and in fact regeneration of neurosecretory axons appears to occur only where a blood-brain barrier is absent 133; unpublished observations/. Blood-borne factors are available at the transection site immediately after placement of the graft due to extravasation at the site, and remain available throughout the observation period within grafts, since fenestrated capillaries are present in all grafts. However, it seems clear that in the absence of glial cells in cryotreated grafts, the availability of serum derived factors is insufficient to initiate neurosecretory axon regeneration.

It is logical to conclude at this point, that glial cells are an essential element in the regenerative process. What role then can glial cells be presumed to play in that process? Glial cells could mediate 

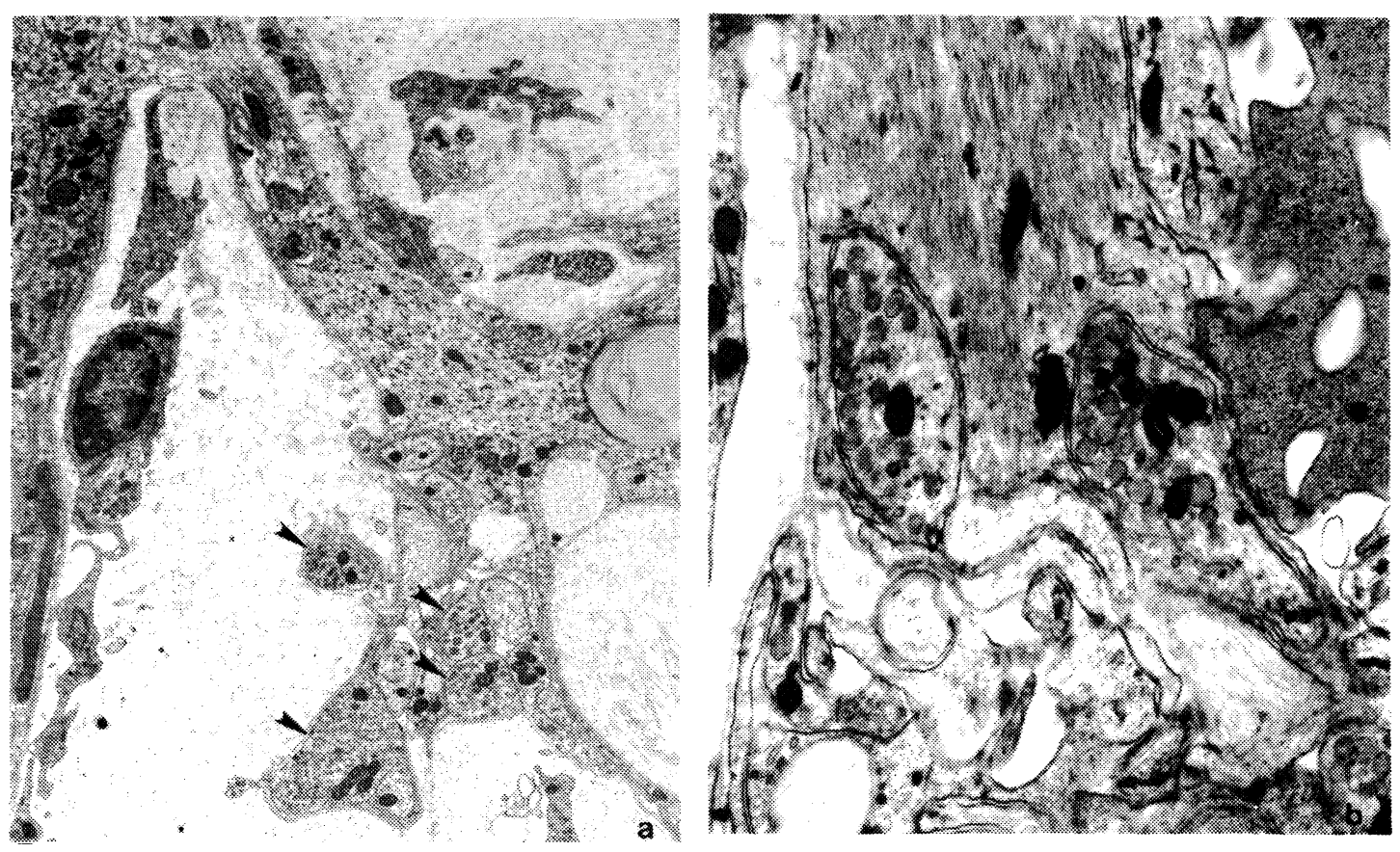

Fig. 7: a: Neurosecretory axons have penetrated a short distance into the periphery of this cryotreated neural lobe transplant along astrocyte processes from the adjacent hypothalamus. $x$ 7200. b: Neurosecretory axons are closely invested by a basal lamina-enclosed astrocyte process in the periphery of a cryotreated sciatic nerve transplant. $x 21000$.

regeneration through direct interaction with the axon, or through release of trophic substances, or both. The close juxtaposition of all 3 types of glial cells with the regenerating neurosecretory axons suggests that axon extension takes place along the glial cell surface; therefore, adhesion molecules are probably involved in the process $/ 33 /$. Candidate molecules are L1, which has been implicated in PNS axonal regeneration $/ 2,5,26,28 /$, and NCAM, which has recently been shown to occur in the hypothalamo-neurohypophysial system /38/. The observations that neurosecretory axons regenerate into cryotreated grafts only when accompanied by basal lamina-ensheathed astrocyte processes, and that they do not grow into the grafts beyond these glial processes, strongly support the notion that the glial cell surface provides a guidance substrate. On the other hand, the fine structural characteristics of transplanted pituicytes are typical of highly secretory cells, and our recent in vitro studies have provided evidence for the existence of a pituicytederived trophic factor for developing neurosecretory neurons (unpublished observations), which could conceivably be operative in adult neurosecretory neurons as well. Such a factor could initiate and sustain regeneration of transected neurosecretory axons. NGF $/ 16,23,40 /$, astrocytederived factors $/ 22,25 /$ and $b F G F / 3,24,35,39 /$ have been shown to be secreted by neurolemmocytes and astrocytes, and could conceivably initiate and promote neurosecretory axon regeneration.

Our experiments clearly support the concept that glial cells are indispensable for neurosecretory axon regeneration, and that serum-derived factors with basal lamina and other extracellular matrix elements alone, provide an insufficiently supportive microenvironment.

\section{REFERENCES}

1. Antunes JL, Carmel PW, Zimmerman EA, Ferin M. Regeneration of the magnocellular system of the rhesus monkey following hypothalamic lesions. Ann Neurol 1978; 5: 462-469.

2. Bunge MB, Bunge RP, Kleitman N, Dean AC. Role of peripheral nerve extracellular matrix in Schwann cell 
function and in neurite regeneration. Dev Neurosci 1989; 11: 348-360.

3. Cancilla PA, Bready J, Berliner J, Sharifi-Nia H, Toga AW, Santori EM, Scully S, deVellis J. Expression of mRNA for glial fibrillary acidic protein after experimental cerebral injury. J Neuropath Exp Neurol 1992; 51: 560-565.

4. Carithers J, Dellmann H-D. Regeneration of neural lobe-like neurovascular contact regions in explanted neural lobes placed in the hypothalamoneurohypophysial tract in the lateral retrochiasmatic area. Brain Res (in press).

5. Daniloff JK, Levi G, Grumet M, Rieger F, Edelman GM. Altered expression of neuronal cell adhesion molecules induced by nerve injury and repair. $\mathrm{J}$ Cell Biol 1986; 103: 929-945.

6. Danilova OA, Polenov AL. "Gomori-positive" neurosecretion in the rat after deafferentation of the medial basal hypothalamus. Cell Tissue Res 1977; 176: 121-130.

7. Dellmann H-D. Degeneration and regeneration of neurosecretory systems. In t Rev Cytol 1973; 36: 215 315.

8. Dellmann H-D, Carithers J. Development of neural lobe-like neurovascular contact regions after intrahypothalamic transection of the hypothalamoneurohypophysial tract. Brain Res 1992; 585: 19-27.

9. Dellmann H-D, Gabrion J, Privat A. Fine structural changes in explants of the neural lobe of the rat hypophysis. J Neuroendocrinol 1991; 3: 339-347.

10. Dellmann H-D, Lue L-F, Bellin SI. Peptidergic neurosecretory axons regenerate into sciatic nerve autografts in the rat hypothalamus. Neuroendocrinology 1986; 44: 292-298.

11. Dellmann H-D, Lue L-F, Bellin SI. Fine structural characteristics of neurophysin-positive perivascular plexus that develop in the rat hypothalamus following interruption of the hypothalamo-neurohypophysial tract. Cell Tissue Res 1987; 247: 137-143.

12. Dellmann H-D, Lue L-F, Bellin SI. Neurosecretory axon regeneration into intrahypothalamic neural lobe allografts: neurophysin immunohistochemistry and fine structure. Exp Brain Res 1987; 67: 534-555.

13. Dellmann H-D, Lue L-F, Bellin SI, Ouassat M. An immunohistochemical and fine structural analysis of peptidergic hypothalamic axon regeneration into the leptomeninges of the rat. Brain Res 1988; 450: 181189.

14. Dellmann H-D, Lue L-F, Bellin SI, Ouassat $M$ Magnaocellular neurosecretory axon regeneration into rat intrahypothalamic optic nerve allografts. J Neurosci Res 1989; 24: 163-168.

15. Hall SM. The effect of inhibiting Schwann well mitosis on the reinnervation of acellular autografts in the peripheral nervous system of the mouse. Neuropath Appl Neurobiol 1986; 12: 401-414.
16. Heumann R, Korsching S, Bandtlow C, Thoenen H. Changes in nerve growth factor synthesis in nonneuronal cells in response to sciatic nerve transection. J Cell Biol 1987; 104: 1623-1631.

17. Ide $C$, Osawa $T$, Tohyama $K$. Nerve regeneration through allogeneic nerve grafts, with special reference to the role of the Schwann cell basal lamina. Prog Neurobiol 1990; 34: 1-38.

18. Ide C, Tohyama K, Yokota R, Onodera S. Schwann cell basal lamina and nerve cell regeneration. Brain Res 1983; 288: 61-75.

19. Karksú S, Tóth J, László FA. Ultrastrukturelle Veränderungen des supraoptico-hypophysären Systems nach Läsion des Hypophysenstiels bei der Ratte. Acta Histochem 1985; 76: 183-192.

20. Keynes RJ, Hopkins WG, Huang CL-H. Regeneration of mouse peripheral nerves in degenerating skeletal muscle: guidance by residual muscle fiber basement membrane. Brain Res 1984; 295-281.

21. Kiernan JA. Hypotheses concerned with axonal regeneration in the mammalian nervous system. Biol Rev 1979; 54: 155-197.

22. Lindsay RM. Reactive gliosis. In: Fedoroff $\mathrm{S}$, Vernadakis A, eds, Astrocytes: Cell Biology and Pathology of Astrocytes, Vol 3. Orlando: Academic Press, 1986; 231-262.

23. Lu B, Yokoyama M, Dreyfuss CF, Black IB. NGF gene expression in actively growing brain glia. J Neurosci 1991; 11: 318-326.

24. Logan A, Frautschy SA, Baird A. Basic fibroblast growth factor and central nervous system injury. Ann NY Acad Sci 1991; 638: 474-476.

25. Manthorpe M, Rudge JS, Varon S. Astroglial cell contributions to neuronal survival and neurite growth. In: Fedoroff S, Vernadakis A, eds, Astrocytes: Biochemistry, Physiology and Pharmacology of Astrocytes, Vol 2. Orlando: Academic Press 1986; 315 376.

26. Martini R, Schachner M. Immunoelectron microscopic localization of neural cell adhesion molecules (L 1, NCAM, and myelin associated glycoprotein) in regenerating adult mouse sciatic nerve. J Cell Biol 1988; 106: 1735-1746.

27. Nagy L, Koves $K$, Réthélyi M, Halász B. Is the knife cut in the hypothalamus a permanent barrier to growth of nerve fibers? - an affirmative answer. Brain Res 1983; 268: 354-358.

28. Nieke J, Schachner M. Expression of neural cell adhesion molecules $\mathrm{K} 1$ and $\mathrm{N}-\mathrm{CAM}$ and their common carbohydrate apitope L2/HNK-1 during development and after transection of the mouse sciatic nerve. Differentiation 1985; 30: 141-151.

29. Osawa $T$, Ide $C$, Tohyama $K$. Nerve regeneration through cryotreated xenogeneic nerve grafts. Arch Histol Jap 1987; 50: 193-208.

30. Palkovits M. Neuropeptides in the hypothalamo- 
hypophysial system: lateral retrochiasmatic area as a common gate frn neuronal fibers towards the median eminence. Peptides 1984; 5: 35-39.

31. Polenov AL, Ugrumov MV, Propp MV, Belenky MA. The hypothalamo-hypophysial system of hypophysectomized rats. I. Ultrastucture of nerve fibers in "intact" and dehydrated animals. Cell Tissue Res 1974; 155: $541-554$.

32. Raisman G. Electron microscopic studies of the development of new neurohemal contacts in the median eninence of the rat after hypophysectomy. Brain Res 1973; 155: 245-262.

33. Rutishauser U, Acheson A, Hall K, Mann DM, Sunshine J. The neural cell adhesion molecule $(\mathrm{N}$ CAM) as a regulator of cell-cell interactions. Science 1988; 240: 53-57.

34. Scott PM, Knigge KM. Immunocytochemistry of luteinizing hormone-releasing hormone, vasopressin, and corticotropin following deafferentation of the basal hypothalamus of the male rat brain. Cell Tissue Res 1981; 219: 245-262.

35. Sievers J. Hausmann B, Unsicker K, Berry $M$.
Fibroblast growth factors promote the survival of adult retinal ganglion cells after transection of the optic nerve. Neurosci Lett 1987; 76: 157-162.

36. Smith GV, Stevenson JA. Peripheral nerve grafts lacking viable Schwann cells fail to support central nervous system axonal regencration. Exp Brain Res 1988; 69: 299-306.

37. Stutinsky F. Sur l'origine de la substance gormoripositive du complexe hypothalamo-neurohypophysaire. C R Soc Biol (Paris) 1951; 145: 367-370.

38. Theodosis DF, Rougon G, Poulain DA. Retention of embryonic features by an adult neuronal system capable of plasticity: polysialylated neuronal cell adhesion molecule in the hypothalamo-neurohypophysial system. Proc Natl Acad Sci USA 1991; 88: 5494-5498.

39. Wallicke PA, Baird A. Internalization and processing of basic fibroblast growth factor by neurons and astrocytes. J Neurosci 1991; 11: 2249-2258.

40. Yoshida K, Gage FH. Fibroblast growth factors stimulate nerve growth factor synthesis and secretion by astrocytes. Brain Res 1991; 538: 118-126. 

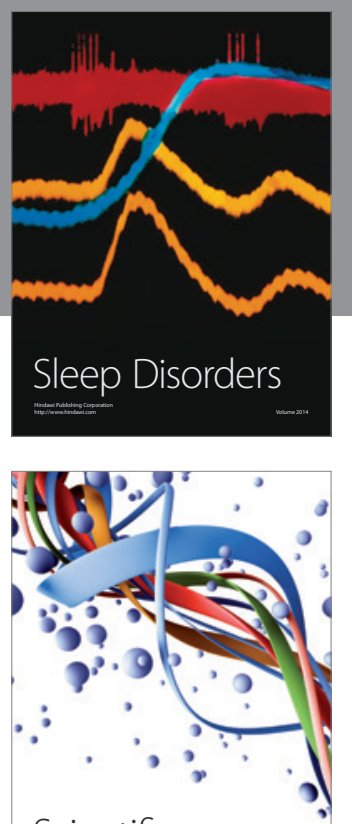

Scientifica
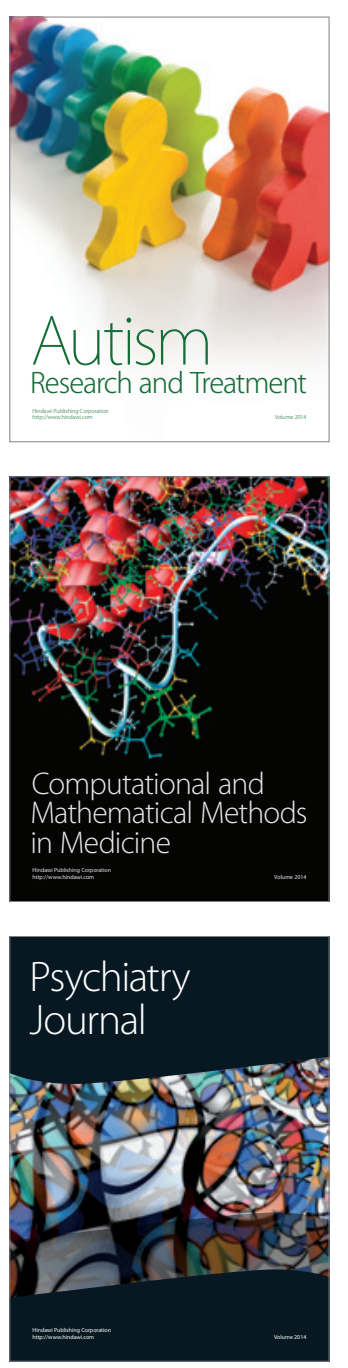
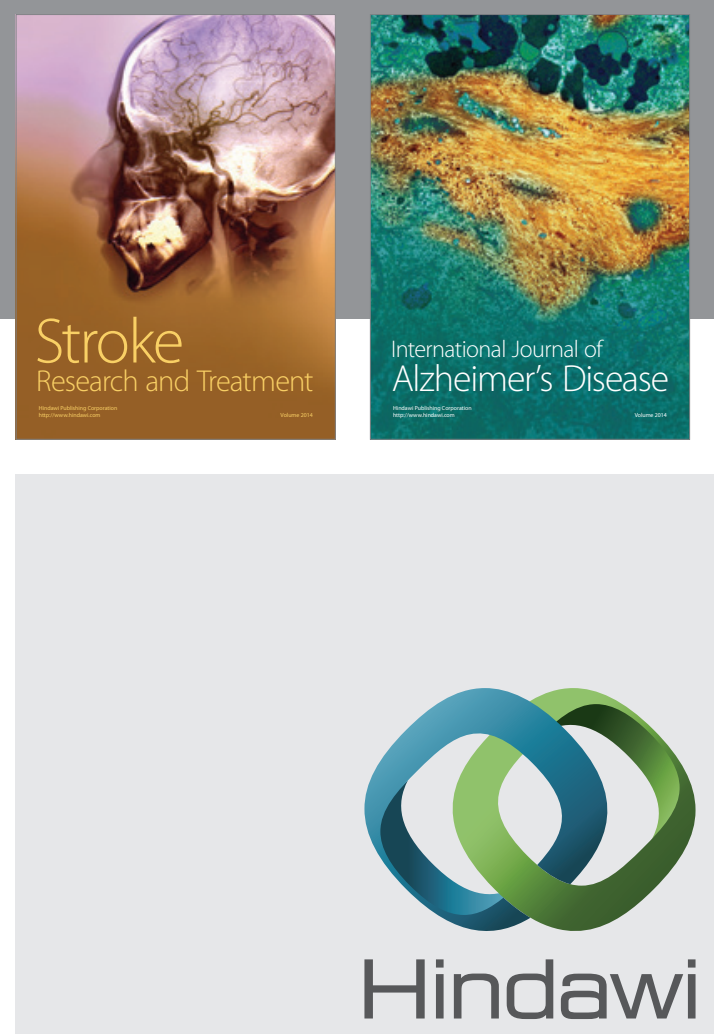

Submit your manuscripts at

http://www.hindawi.com
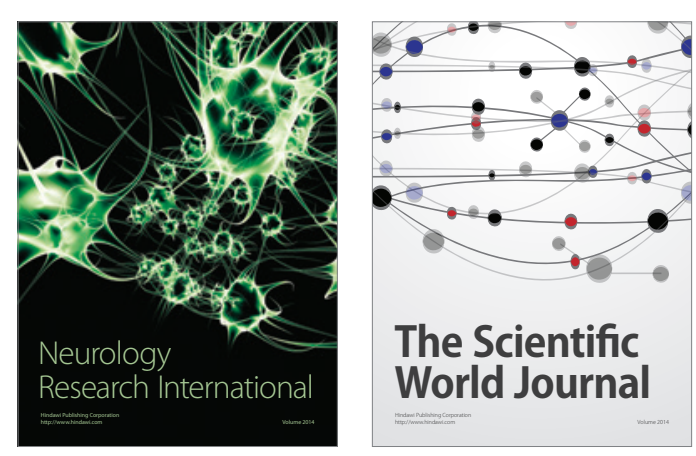

The Scientific World Journal

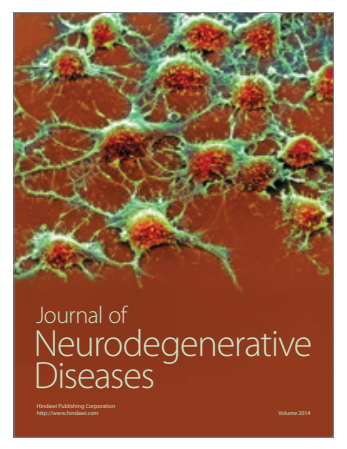

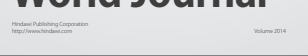

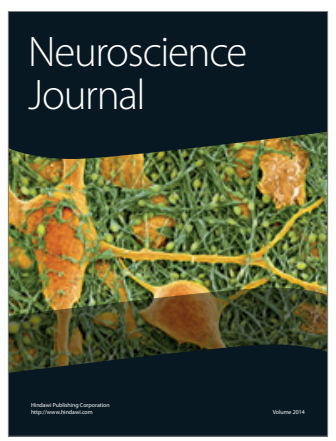

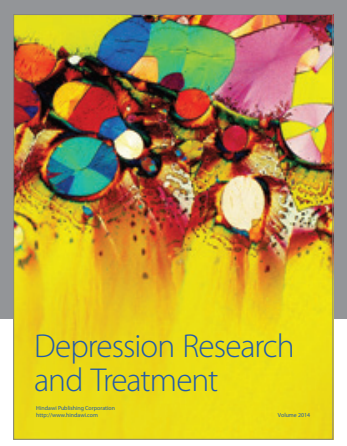
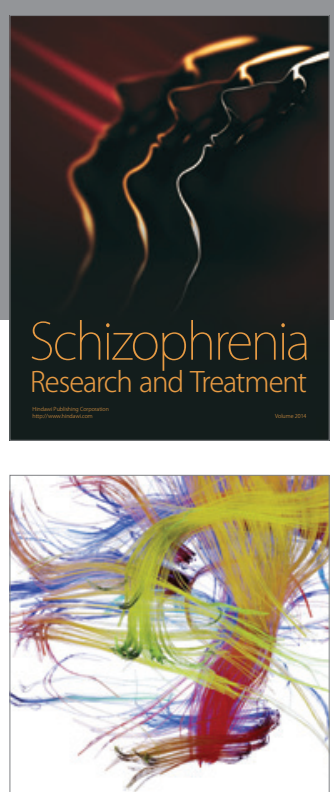

Brain Science

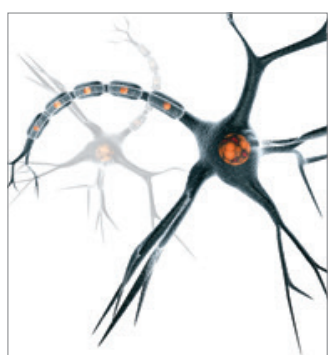

Neural Plasticity
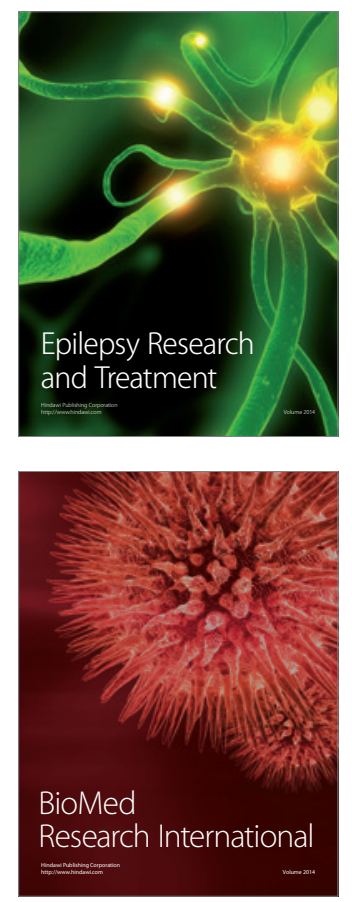

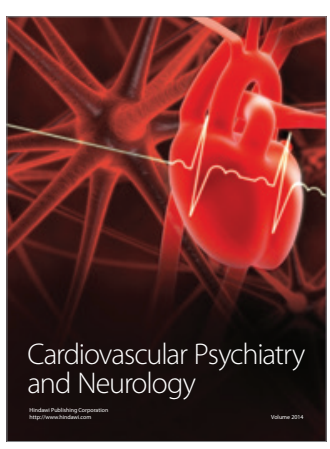

Parkinson's

Disease
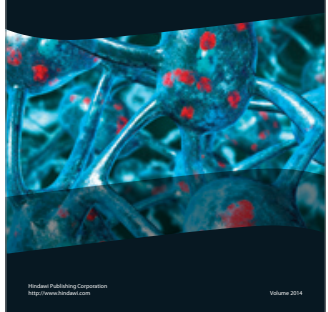